\title{
Keterampilan Mengajar Guru PAUD dalam Pembelajaran Daring
}

\section{Ida Ayu Made Partami*1*, I Wayan Sujana²}

1,2 Pendidikan Guru Pendidikan Anak Usia Dini, Universitas Pendidikan Ganesha, Singaraja, Indonesia

\section{AR T I C L E I N F O}

Article history:

Received 16 April 2021

Revised 17 April 2021

Accepted 06 Juni 2021

Available online 25 Agustus 2021

Kata Kunci:

Keterampilan Mengajar Berbasis Daring

Keywords:

Online-Based Teaching Skills

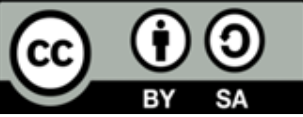

This is an open access article under the CC BY-SA license.

Copyright (@) 2021 by Author. Published by Universitas Pendidikan Ganesha.

\begin{abstract}
A B S T R A K
Adanya kebijakan pelaksanaan pembelajaran jarak sebagai salah satu cara pencegahan penyebaran virus corona (COVID-19) menyebabkan guru-guru harus mempersiapkan pembelajaran dengan seefisien mungkin, sehingga keterampilan mengajar guru sangat berperan penting dalam pelaksanaan pembelajaran daring. Penelitian ini bertujuan untuk mendeskripsikan keterampilan mengajar guru dalam pembelajaran berbasis daring yang dilaksanakan pada masa pandemi covid-19. Penelitian ini menggunakan rancangan penelitian survei deskriptif dengan pendekatan kuantitatif. Populasi penelitian ini adalah guru PAUD yang berada di wilayah Denpasar Utara dengan jumlah sampel sebanyak 179 orang. Metode pengumpulan data yang digunakan pada penelitian ini adalah metode non tes dengan penyebaran kuisioner/angket. Instrument yang digunakan dalam penelitian ini berupa kusioner dengan jenis kuisioner tertutup. Data yang telah dikumpulkan kemudian dianalisis dengan menggunakan analisis statistik deskriptif. Hasil penelitian ini menunjukkan bahwa berdasarkan survei yang telah dilaksanakan diperoleh hasil keterampilan mengadakan variasi berbasis daring memperoleh persentase sebesar $75,72 \%$ (positif), keterampilan bertanya berbasis daring memperoleh persentase sebesar $74,35 \%$ (positif), dan keterampilan memberi penguatan berbasis daring memperoleh persentase sebesar $80,49 \%$ (positif). Sehingga dapat disimpulkan bahwa dalam pelaksanaan pembelajaran daring guru sudah mampu menerapkan keterampilan mengajar berbasis daring sesuai dengan karakteristiknya dengan baik dilihat dari keterampilan mengadakan variasi berbasis daring, keterampilan bertanya, dan keterampilan memberi penguatan kegiatan belajar dalam jaringan (daring).
\end{abstract}

\section{A BS TRACT}

The existence of government policies related to the implementation of distance learning as a way to prevent the spread of the corona virus (COVID-19) causes teachers must prepare learning as efficiently as possible, so teacher teaching skills play an important role in the implementation of online learning. This study aims to describe the teaching skills of teachers in online-based learning carried out during the covid-19 pandemic. This study uses a descriptive survey research design with a quantitative approach. The population of this study were PAUD teachers in the North Denpasar area with a total sample of 179 people. The data collection method used in this study is a non-test method with the distribution of questionnaires/questionnaires. The instrument used in this study was a questionnaire with a closed type of questionnaire. The data that has been collected is then analyzed using descriptive statistical analysis. The results of this study indicate that based on the survey that has been carried out, the results obtained are online-based variation skills get a percentage of $75.72 \%$ (positive), online-based questioning skills get a percentage of $74.35 \%$ (positive), and skills to provide online-based reinforcement obtained a percentage of $80.49 \%$ (positive). So it can be concluded that in the implementation of online learning the teacher has been able to apply online-based teaching skills according to their characteristics well seen from the skills of conducting online-based variations, questioning skills, and skills provide reinforcement of learning activities in the network (online). 


\section{PENDAHULUAN}

Usia dini merupakan masa yang tepat untuk mengembangkan dan meningkatkan kompetensi dan keterampilan anak (Permanasari et al., 2018). Hal ini dikarenakan pada masa ini anak mulai senitif dan peka dalam menerima rangsangan dari luar, sehingga sangat penting untuk memberikan stimulasi yang tepat kepada anak agar dapat mengoptimalkan aspek-aspek perkembangan anak (Subarkah, 2019; Yuniarni, 2016). Pengoptimalan aspek-aspek perkembangan anak pada usia dini dapat dilaksanakan dengan berbagai macam cara salah satunya dengan mengikutsertakan anak dalam pendidikan anak usia dini (PAUD). Kegiatan pembelajaran dalam pendidikan anak usia dini pada umumnya dilakukan melalui tatap muka secara langsung di dalam kelas. Namun, karena adanya pandemi covid 19, menyebabkan terjadi perubahan sistem pembelajaran sehingga membuat proses pembelajaran yang awalnya dilakukan secara tatap muka berubah menjadi pembelajaran daring (Suhendro, 2020). Pembelajaran daring merupakan sistem pembelajaran yang dilakukan dengan tidak bertatap muka langsung antara guru maupun siswa dengan menggunakan digital platform atau menggunakan model interaktif berbasis Internet dan Learning Manajemen System (LMS) (Asmuni, 2020; Fitriyani et al., 2020). Pembelajaran daring dilaksanakan dengan bantuan teknologi seperti menggunakan zoom meeting, google classroom, youtube, maupun penggunaan whatsapp group, selain itu, pemerintah juga menyiapkan beberapa fasilitas untuk menunjang pembelajaran jarak jauh misalnya siaran pembelajaran melalui TV dan radio, maupun penyediaan kuota gratis/murah (Ayudia et al., 2020; Harahap et al., 2021). Dalam pelaksanaan pembelajaran daring ini guru harus dapat menciptakan suasana pembelajaran yang efektif dan efisien agar tetap tercapainya tujuan pembelajaran (Saifulloh \& Darwis, 2020).

Penetapan kebijakan belajar dengan sistem daring memberikan dampak pada perubahan sistem pembelajaran. Pembelajaran yang awalnya dilakukan secara tatap muka di sekolah diubah menjadi pembelajaran online (Srihartini \& Lestari, 2021). Dalam kegiatan pembelajaran daring anak tidak dapat bermain dan melakukan pembelajaran secara langsung dengan teman sebayanya, padahal dengan bermain dan bertemu teman sebaya secara langsung dapat melatih aspek perkembangan anak (Bungsu \& Saridewi, 2021; Palestina, 2021). Hal tersebut kemudian berdampak pada perkembangan anak baik dari aspek nilai agama dan moral, fisik-motorik, kognitif, bahasa, sosial emosional, dan seni. Hal ini tentunya bertentangan dengan karaktersitik pembelajaran anak usai dini. Dimana karakteristik pembelajaran di PAUD yang seharusnya menggunakan sistem pembelajaran dengan bermain sambil belajar, karena adanya pandemi membuat siswa dilarang untuk melaksanakan pembelajaran secara langsung sehingga siswa merasa bosan dan ingin ke sekolah untuk bertemu teman sebayanya (Fadlilah, 2020; Harahap et al., 2021). Jika hal ini terus terjadi, maka akan berdampak terhadap perkembangan dan hasil belajar anak.

Untuk mengatasi hal tersebut guru PAUD dituntut untuk mampu menghadirkan suasana pembelajaran yang aktif dan efektif dengan cara mengembangakan keterampilan mengajarnya agar dapat menyesuaikan dengan pembelajaran daring, sehingga pembelajaran dapat berlangsung secara efektif dan tujuan pembelajaran dapat tetap tercapai dengan baik. Keterampilan mengajar guru harus dapat dikembangakan seefisien mungkin agar anak tetap merasa senang belajar walau hanya belajar di rumah. Keterampilan mengajar pada dasarnya merupakan salah satu manifestasi dari kemampuan seorang guru sebagai tenaga professional (Taufik, 2018). Keterampilan mengajar guru dalam kegaiatan pembelajaran secara umum dapat terdiri dari keterampilan membuka dan menutup pelajaran, keterampilan menjelaskan, keterampilan bertanya, keterampilan memberi penguatan, keterampilan membimbing diskusi kelompok kecil, keterampilan mengelola kelas, keterampilan mengadakan variasi, keterampilan mengajar perorangan dan kelompok kecil (Nuralan \& Daipatama, 2020; Sundari \& Muliyawati, 2017).

Dalam pelaksanaan pembelajaran daring tentunya tidak semua keterampilan dapat diterapkan oleh guru, salah satu keterampilan yang dapat digunakan guru dalam mengajar dengan sistem daring/online diantaranya keterampilan mengadakan variasi, keterampilan bertanya, dan keterampilan memberi penguatan. Keterampilan mengadakan variasi merupakan keterampilan yang berkaitan dengan kegiatan guru dalam konteks interaksi pembelajaran dengan tujuan untuk meningkatkan motivasi belajar siswa dan sekaligus untuk mengurangi rasa jenuh/bosan, serta dapat menimbulkan gairah, minat, dan aktifitas belajar yg efektif (Aulia, 2018; Kurniati \& Liani, 2019). Dengan sistem pembelajaran berbasis daring ini keterampilan mengadakan variasi dibutuhkan untuk mengatasi kebosanan dalam proses pembelajaran. Keterampilan bertanya ialah kegiatan interaksi guru dan siswa dalam proses pembelajaran yang diharapkan dapat mengaktifkan siswa untuk berpartisipasi dan membangkitkan rasa ingin tahu siswa dalam pembelajaran (Habibi \& Firmansyah, 2019). Keterampilan bertanya bertujuan untuk merangsang pengetahuan anak, dengan sistem pembelajaran berbasis daring ini komunikasi antara guru dan peserta didik di dampingi oleh para orang tua peserta didik atau bisa dikatakan proses pembelajaran dilaksanakan melalui para orang tua dalam menyalurkan informasi kepada peserta didik, maka seorang guru harus mengerti cara untuk mengajukan pertanyaan yang berpengaruh positif bagi kegiatan belajar siswa. Keterampilan memberi penguatan adalah kegiatan guru dalam memberikan respon/feedback 
positif kepada siswa yang bertujuan untuk mempertahankan dan meningkatkan tingkah laku positif yang telah dilakukan siswa (Achdiani \& Rusliyani, 2017; Mufidah \& Asmawi, 2017). Keterampilan ini sangat berkaitan dengan keterampilan bertanya, dimana seorang guru memberikan feedback dari pertanyaan tersebut dengan penguatan yang sesuai, pemberian penguatan ini sangat berpengaruh terhadap perkembangan peserta didik.

Beberapa penelitian sebelumnya yang berkaitan dengan keterampilan mengajar guru selama proses pembelajaran daring menyebutkan bahwa keterampilan mengajar guru sangat diperlukan dalam pelaksanaan pembelajaran daring, hal ini dikarenakan keterampilan mengajar guru dapat meningkatkan motivasi dan semangat siswa untuk belajar (Ayuni et al., 2020; Sukitman, Trizid, 2020). Penelitian lainnya juga menyebutkan bahwa 4 dari 10 guru TK masih belum terampil dalam melaksanakan pembelajaran daring, sehingga berdampak pada penurunan tingkat kemampuan siswa (Ayuni et al., 2020). Penelitian selanjutnya juga menyatakan bahwa skema pembelajaran yang dilakukan PAUD yang ada di Kabupaten Ponorogo selama masa pandemi Covid 19 yaitu dengan pembelajaran dalam jaringan, dan keterampilan yang digunakan guru khususnya pemberian penguatan yang dilakukan oleh guru selama masa pandemi COVID-19 terdiri dari penguatan verbal dan non verbal (Setyowahyudi \& Ferdiyanti, 2020). Berdasarkan beberapa penelitian tersebut dapat dikatakan bahwa tidak semua guru memiliki kemampuan untuk melaksanakan pembelajaran secara daring. Guru yang mampu melaksanakan pembelajaran daring memiliki keterampilan yang berbeda-beda dalam melaksanakan pembelajaran daring, sehingga tujuan dari penelitian ini yakni untuk mendeskripsikan keterampilan mengajar guru dalam dalam melaksanakan pembelajaran berbasis daring pada masa pandemi covid-19. Keterampilan mengajar yang dimaksud dalam penelitian ini dibagi menjadi tiga aspek yaitu keterampilan mengadakan variasi, keterampilan bertanya, dan keterampilan memberikan penguatan dalam pembelajaran daring.

\section{METODE}

Penelitian ini merupakan jenis penelitian survey deskriptif yang dilaksanakan dengan pendekatan kuantitatif. Populasi dalam penelitian ini, yakni semua guru PAUD yang ada di wilayah Denpasar Utara yang berjumlah 322 guru, sesuai dengan data Dinas Pendidikan Kepemudaan Dan Olahraga (DISDIKPORA) Kota Denpasar tahun ajaran 2020/2021. Selanjutnya, karena tidak memungkinkan untuk melakukan penelitian pada seluruh populasi maka untuk mewakili populasi guru PAUD ditentukan sampel penelitian dengan menggunakan teknik Proportional Random Sampling. Berdasarkan perhitungan yang telah dilakukan diperoleh jumlah sampel sebesar 179. Rincian mengenai sebaran sampel penelitian dapat dilihat pada tabel 1.

Tabel 1. Sebaran data sampel penelitian

\begin{tabular}{|c|c|c|}
\hline No & Nama wilyah & Jumlah sampel \\
\hline 1 & Pemecutan Kaja & 33 \\
\hline 2 & Dauh Puri Kaja & 14 \\
\hline 3 & Dangin Puri Kauh & 3 \\
\hline 4 & Dangin Puri Kaja & 7 \\
\hline 5 & Dangin Puri Kangin & 11 \\
\hline 6 & Peguyangan & 13 \\
\hline 7 & Ubung & 14 \\
\hline 8 & Ubung Kaja & 21 \\
\hline 9 & Peguyangan Kaja & 18 \\
\hline 10 & Peguyangan Kangin & 18 \\
\hline 11 & Tonja & 27 \\
\hline
\end{tabular}

Metode pengumpulan data yang digunakan pada penelitian ini adalah metode non tes dengan penyebaran angket/kuisioner. Instrumen yang digunakan dalam penelitian ini adalah berupa kuesioner tertutup yang berorientasi pada keterampilan mengajar berbasis daring. Uji validitas instrument menggunakan uji validitas isi yang dikembangkan oleh Robert Gregory. Adapun kisi-kisi instrument penelitian keterampilan mengajar berbasis daring disajikan pada Tabel 2. Metode analisis data yang digunakan dalam penelitian ini yaitu menggunakan metode analisis statistik deskriptif kuantitatif. Kemudian data yang diperoleh berupa skor hasil pengisian kusioner/angket oleh guru dianalisis mengggunakan teknik analisis statistik deskriptif berupa penentuan mean dan persentase data. 
Tabel 2. Kisi-Kisi Instrumen Penelitian Keterampilan Mengajar Berbasis Daring

\begin{tabular}{|c|c|c|c|}
\hline Variabel & Sub Variabel & Aspek & Indikator \\
\hline \multirow{21}{*}{$\begin{array}{l}\text { Keterampilan } \\
\text { Mengajar Guru }\end{array}$} & \multirow{8}{*}{$\begin{array}{l}\text { Keterampilan } \\
\text { Mengadakan } \\
\text { Variasi }\end{array}$} & & Gaya Mengajar Klasik \\
\hline & & Varıası Gaya & Gaya Mengajar Teknologis \\
\hline & & & Gaya Mengajar Personalisasi \\
\hline & & \multirow{3}{*}{$\begin{array}{l}\text { Variasi media } \\
\text { dan bahan ajar }\end{array}$} & Penggunaan media dan bahan ajar untuk \\
\hline & & & $\begin{array}{l}\text { meningkatkan semangat } \quad \text { siswa dalam } \\
\text { pembelajaran daring }\end{array}$ \\
\hline & & & $\begin{array}{l}\text { Pemilihan media sesuai tujuan pembelajaran } \\
\text { dan karakteristik peseta didik }\end{array}$ \\
\hline & & \multirow{2}{*}{$\begin{array}{l}\text { Variasi Pola } \\
\text { Interaksi }\end{array}$} & $\begin{array}{l}\text { Penggunaan Media dan bahan ajar aplikasi } \\
\text { secara digital }\end{array}$ \\
\hline & & & $\begin{array}{l}\text { Pembelajaran tatap muka dengan menggunakan } \\
\text { kelas virtual. }\end{array}$ \\
\hline & \multirow{8}{*}{$\begin{array}{l}\text { Keterampilan } \\
\text { Bertanya }\end{array}$} & & $\begin{array}{l}\text { Pertanyaan yang diberikan jelas dan singkat, } \\
\text { serta penyusunan kata-kata dalam pertanyaan }\end{array}$ \\
\hline & & Keterampilan & disesuaikan dengan usia dan tingkat \\
\hline & & Tingkat Dasar & Pemberian acuan beruna nertanvaan vang berisi \\
\hline & & & informasi yang relevan dengan jawaban yang \\
\hline & & \multirow{4}{*}{$\begin{array}{c}\text { Keterampilan } \\
\text { Bertanya } \\
\text { Tingkat } \\
\text { Lanjutan }\end{array}$} & diharapkan dari siswa. \\
\hline & & & Pertanyaan diurutkan mulai pertanyaan \\
\hline & & & $\begin{array}{l}\text { sederhana ke tingkat pertanyaan yang lebih } \\
\text { sulit, seperti memberikan pertanyaan yang } \\
\text { bersifat pemahaman, aplikasi (penerapan), } \\
\text { analisis dan sintesis, evaluasi, dan kreasi. }\end{array}$ \\
\hline & & & $\begin{array}{l}\text { Membimbing siswa dalam mengembangkan idea } \\
\text { tau gagsan yang dimiliki. }\end{array}$ \\
\hline & \multirow{5}{*}{$\begin{array}{l}\text { Keterampilan } \\
\text { Memberi } \\
\text { Penguatan }\end{array}$} & Berbentuk & Pemberian feedback berupa kata-kata dan \\
\hline & & Verbal & $\begin{array}{l}\text { kaliamat pujian, nasihat dan dorongan positif } \\
\text { yang bertujuan untuk memotivasi anak. }\end{array}$ \\
\hline & & & Pemberian penguatan secara tidak langsung \\
\hline & & Berbentuk & dalam pembelajaran secara virtual \\
\hline & & Non Verbal & $\begin{array}{l}\text { Penggunaan penguatan yang divariasikan sesuai } \\
\text { dengan situasi dan kondisi pembelajaran. }\end{array}$ \\
\hline
\end{tabular}

\section{HASIL DAN PEMBAHASAN}

Hasil

Temuan pada penelitian ini berkaitan dengan 3 aspek keterampilan guru dalam mengajar yang terdiri dari aspek keterampilan mengadakan variasi, keterampilan bertanya, dan keterampilan memberi penguatan. Temuan pertama, berkaitan dengan keterampilan mengadakan variasi dalam pembelajaran untuk anak usia dini berbasis daring. Keterampilan mengadakan variasi merupakan kegiatan guru dalam menciptakan berbagai macam kreasi pembelajaran agar siswa tidak merasa bosan dalam melakukan pembelajaran. Keterampilan mengadakan variasi yang diteliti dalam penelitian ini yaitu terdiri dari gaya mengajar klasik, gaya mengajar teknologi, gaya mengajar personalia, penggunaan media dan bahan ahar, pemilihan media yang sesuai dengan tujuan pembelajaran dan karakteristik siswa, penggunaan media dan bahan ajar aplikasi secara digital. Berikut ini merupakan grafik capaian dari keterampilan mengadakan variasi dalam pelaksanaan pembelajaran daring dari masing-masing indikator yang disajikan pada Gambar 1. 


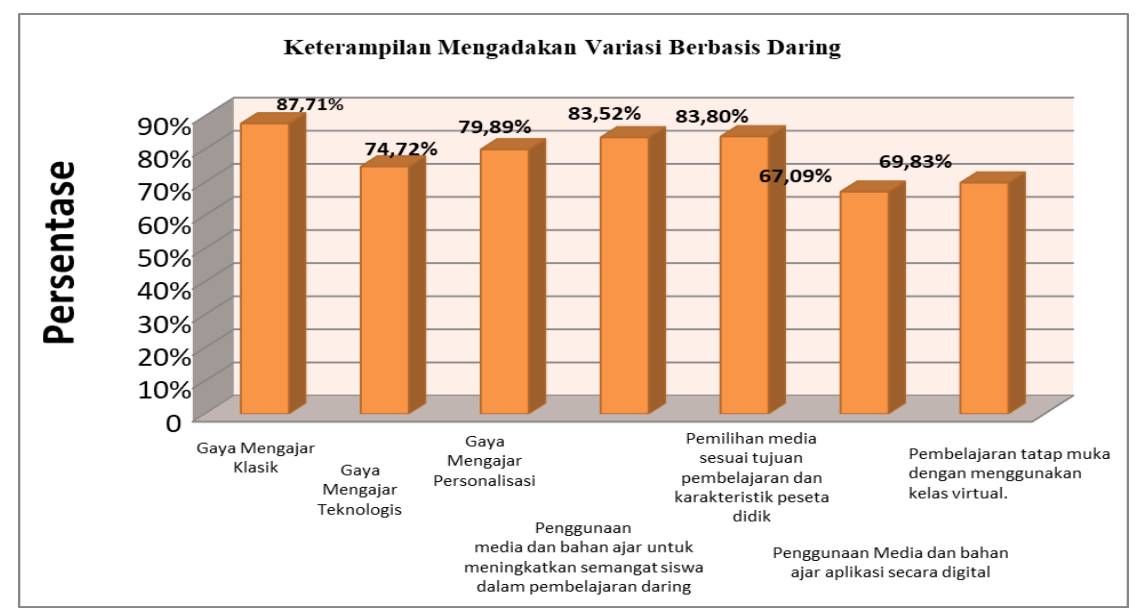

Gambar1. Survei Keterampilan Mengadakan Variasi dalam Pembelajaran Berbasis Daring

Berdasarkan grafik pada Gambar 1 diperoleh hasil bahwa pada indikator pertama yaitu gaya mengajar klasik memperoleh persentase sebesar 87,71\% yang termasuku ke dalam kriteria Sangat positif. Seanjutnya, indikator yang kedua yakni gaya mengajar teknologis memperoleh persentase sebesar $74,72 \%$ yang termasuk ke dalam kriteria positif. Indikator yang ketiga yakni gaya mengajar personalisasi memperoleh persentase sebesar 79,89\% yang termasuk ke dalam kriteria positif. Indikator yang keempat yakni penggunaan media dan bahan ajar untuk meningkatkan semangat siswa dalam pembelajaran daring memperoleh persentase sebesar 83,52\% yang termasuk ke dalam kriteria positif. Indikator yang kelima yakni pemilihan media sesuai tujuan pembelajaran dan karakteristik peserta didik memperoleh persentase sebesar 83,80\% yang termasuk ke dalam kriteria positif. Indikator yang keenam yakni penggunaan media dan bahan ajar aplikasi secara digital memperoleh persentase sebesar 67,09\% yang termasuk ke dalam kriteria kurang positif. Dan indikator yang terakhir yaitu pembelajaran tatap muka dengan menggunakan kelas virtual memperoleh persentase sebesar 69,83\% yang termasuk kriteria kurang positif. Sehingga, secara keseluruhan hasil perhitungan seluruh indikator pada keterampilan mengadakan variasi berbasis daring, diperoleh persentase rerata sebesar $75,72 \%$ yang termasuk ke dalam kriteria positif. Hal ini menggambarkan bahwa sebagian besar guru PAUD sudah mampu menyesuaikan pelaksanaan pembelajaran dengan berbasis virtual.

Temuan kedua, berkaitan dengan keterampilan bertanya dalam pembelajaran untuk anak usia dini berbasis daring. Keterampilan Bertanya merupakan kegiatan guru dalam melakukan interaksi dengan siswa guna untuk merangsang pengetahuan siswa terkait materi pembelajaran yang diberikan. Keterampilan bertanya yang diteliti dalam penelitian ini yaitu terdiri dari pertanyaan yang diberikan jelas dan singkat, pemberian acuan berupa pertanyaan yang berisi informasi relevan, pertanyaan yang diurutkan dari pertanyaan sederhana ke pertanyaan yg lebih sulit, dan membimbing siswa dalam mengembangkan ide dan gagasannya. Berikut ini merupakan grafik capaian dari keterampilan bertanya guru dalam pelaksanaan pembelajaran daring dari masing-masing indikator yang disajikan pada Gambar 2.

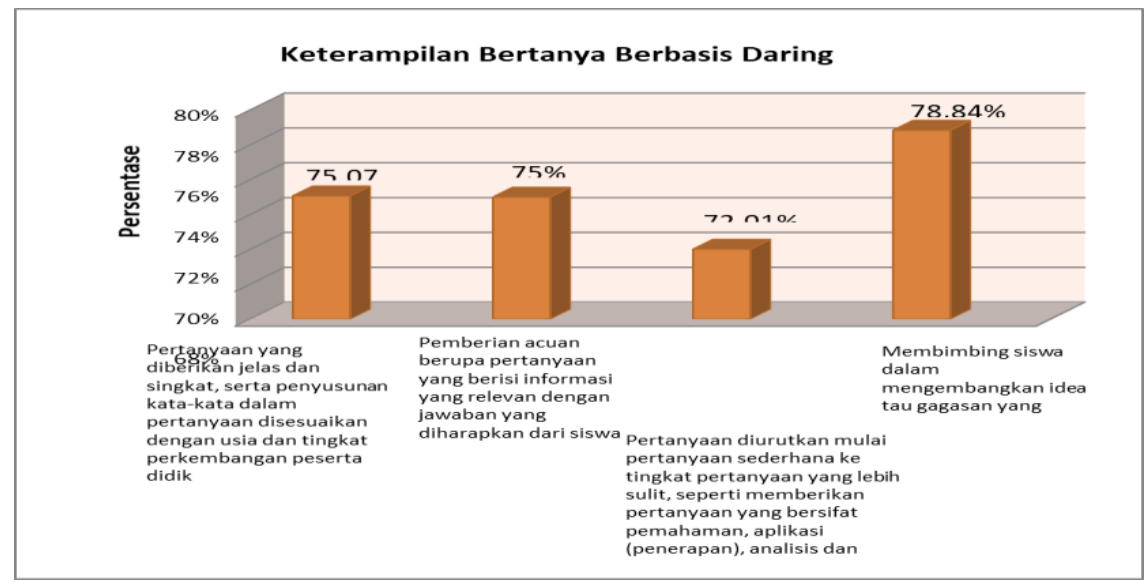

Gambar 2. Survei Keterampilan Bertanya dalam Pembelajaran Berbasis Daring 
Berdasarkan grafik pada Gambar 2 diperoleh hasil bahwa pada indikator pertama yaitu pertanyaan yang diberikan jelas dan singkat, serta penyusunan kata-kata dalam pertanyaan disesuaikan dengan usia dan tingkat perkembangan peserta didik memperoleh persentase sebesar 75,07\% yang termasuk ke dalam kriteria positif. Indikator yang kedua yakni pemberian acuan berupa pertanyaan yang berisi informasi yang relevan dengan jawaban yang diharapkan dari siswa memperoleh persentase sebesar $75 \%$ yang termasuk ke dalam kriteria positif. Indikator yang ketiga yakni pertanyaan diurutkan mulai pertanyaan sederhana ke tingkat pertanyaan yang lebih sulit, seperti memberikan pertanyaan yang bersifat pemahaman, aplikasi (penerapan), analisis dan sintesis, evaluasi, dan kreasi memperoleh persentase sebesar $72,01 \%$ yang termasuk ke dalam kriteria positif. Dan, indikator yang keempat yaitu membimbing siswa dalam mengembangkan idea tau gagsan yang dimiliki memperoleh persentase sebesar 78,84\% yang termasuk ke dalam kriteria positif. Sehingga, hasil perhitungan seluruh indikator pada keterampilan bertanya berbasis daring, diperoleh persentase rerata sebesar 74,35\% yang termasuk ke dalam kriteria positif. Hal ini menggambarkan bahwa guru telah mampu memodifikasi keterampilan bertanya yang dimilikinya disesuaikan dengan pembelajaran daring.

Temuan ketiga, berkaitan dengan keterampilan memberikan penguatan dalam pembelajaran untuk anak usia dini berbasis daring. Keterampilan memberikan penguatan merupakan kegiatan guru dalam memberikan feedback/respon positif terhadap siswa guna mempertahankan dan meningkatkan perilaku positif yang telah dilakukan siswa. Keterampilan memberi penguatan yang diteliti dalam penelitian ini yaitu terdiri dari pemberian feedback berupa kata-kata pujian, nasihat, atau dorongan, pemberiang penguatan secara tidak langsung dalam pembelajaran virtual, dan penggunaan penguatan yang divariasikan sesuai situasi dan kondisi pembelajaran. Berikut ini merupakan grafik capaian dari keterampilan memberikan penguatan oleh guru dalam pelaksanaan pembelajaran daring dari masingmasing indikator yang disajikan pada Gambar 3.

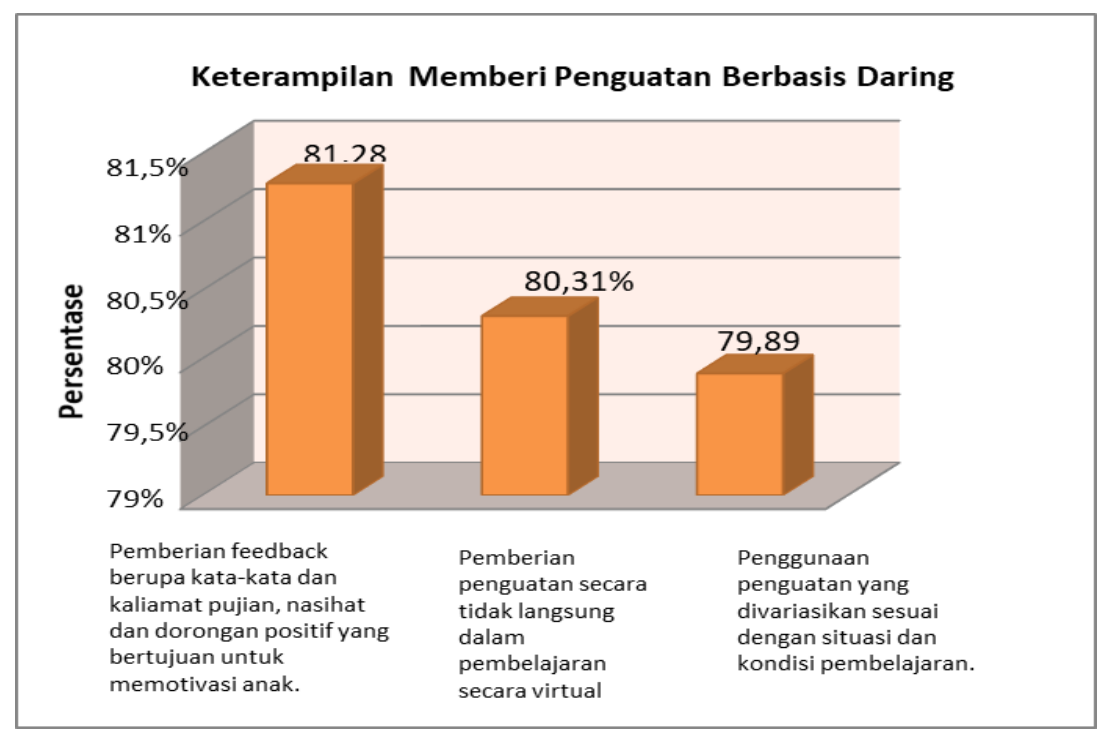

Gambar 3. Survei Keterampilan Memberi Penguatan dalam Pembelajaran Berbasis Daring

Berdasarkan grafik pada Gambar 3 diperoleh hasil bahwa pada indikator pertama yaitu pemberian feedback berupa kata-kata dan kalimat pujian, nasihat dan dorongan positif yang bertujuan untuk memotivasi anak memperoleh persentase sebesar $81,28 \%$ yang termasuk ke dalam kriteria positif. Indikator yang kedua yakni pemberian penguatan secara tidak langsung dalam pembelajaran secara virtual memperoleh persentase sebesar 80,31\% yang termasuk ke dalam kriteria positif. Indikator ketiga yaitu penggunaan penguatan yang divariasikan sesuai dengan situasi dan kondisi pembelajaran memperoleh persentase sebesar 79,89\% yang termasuk ke dalam kriteria positif. Sehingga, hasil perhitungan seluruh indikator pada keterampilan memberi penguatan berbasis daring, diperoleh persentase rerata sebesar $80,49 \%$ yang termasuk ke dalam kriteria positif. Hal ini menggambarkan bahwa guru telah mampu menyesuaikan keterampilannya dalam melaksanakan pembelajaran daring.

\section{Pembahasan}

Berdasarkan analisis hasil penelitian ditemukan bahwa keterampilan mengajar guru PAUD dilihat dari aspek keterampilan mengadakan variasi berbasis daring menunjukkan hasil yang baik, terlihat dari guru yang sudah mampu mengemas pembelajaran dengan sedemikian rupa agar dapat menarik perhatian 
anak. Hal ini menunjukan bahwa guru sudah mampu menerapkan karakteristik keterampilan mengadakan variasi berbasis daring dengan baik, yang mana seorang guru harus memiliki keterampilan dasar mengajar yang baik salah satunya dapat mengadakan variasi agar pembelajaran menjadi menarik dan anak fokus sehingga tujuan pembelajaran dapat tercapai. Solusi dalam menghadapi siswa dengan beragam criteria sehingga di butuhkan variasi dalam pembelajaran. Variasi yang diberikan jika berhasil mengenai sarana atau selaras dengan apa yang dibutuhkan anak, maka selama proses pembelajaran akan ada timbal balik antara guru dan siswa (Jaya, 2017). Guru sebagai panutan yang utama di dalam sebuah kelas yang mengarahkan siswa dalam pembelajaran akan dimudahkan dengan keterampilan mengadakan variasi yang digunakan, sehingga mampu membangkitkan motivasi belajar siswa. Proses pelaksanaan kegiatan belajar dalam jaringan (daring) terhadap keterampilan mengajar guru termasuk dalam kategori baik dimana keterampilan dalam mengadakan variasi media pembelajaran pun dilakukan guru dengan baik (Subakti \& Handayani 2021).

Penelitian ini juga menemukan bahwa keterampilan mengajar guru PAUD dilihat dari aspek keterampilan bertanya berbasis menunjukkan hasil yang baik, terlihat dari pertanyaan yang diberikan guru jelas dan singkat, serta penyusunan kata-kata dalam pertanyaan juga telah disesuaikan dengan usia dan tingkat perkembangan anak. Keterampilan bertanya merupakan keterampilan yang digunakan untuk mendapatkan jawaban/ balikan dari orang lain (Sunarto \& Rohita, 2021; Zein \& Maielfi, 2020). Keterampilan bertanya yang perlu dikuasai guru yaitu bertanya dasar dan bertanya lanjutan. Dalam pembelajaran berbasis daring keterampilan bertanya tidak boleh dilupakan karena keterampilan berfungsi dalam menarik anak ke dalam suatu topic pembelajaran dan tanpa disadari merangsang kemampuan anak dalam mengkolaborasikan kemampuan motorik, kognitif dan bahasa yang berkembang beriringan dengan usia manusia. Proses tanya jawab menyebabkan semakin dekatnya hubungan antara guru dan siswa, sehingga dapat meningkatkan rasa kepercayaan diri siswa (Putri et al., 2017).

Selanjutnya temuan ketiga menunjukkan bahwa keterampilan mengajar guru PAUD dilihat dari aspek keterampilan memberi penguatan berbasis daring menunjukkan hasil yang baik, terlihat dari guru dalam pelaksanaan pembelajaran daring selalu memberikan motivasi-motivasi kepada anak agar tetap semangat untuk belajar. Hal ini menunjukkan bahwa guru sudah mampu menerapkan karakteristik keterampilan memberi penguatan berbasis daring dengan baik. Dampak positif yang diberikan jika pemberi penguatan secara tepat yaitu memberikan motivasi untuk menunjukkan kemampuan, mengelola tingkah laku dengan memhami respon yang diterima sehingga dapat meningkatkan perilaku prososial anak. Mengingat begitu pentingnya memberikan penguatan maka keterampilan dalam memberikan penguatan harus disesuaikan guru dengan cara pemberian materi dengan metode yang tidak sesuai pembelajaran daring akan menambah kejenuhan dalam proses pembelajaran, serta menimbuklan dampak seperti rasa kepercayaan diri yang menurun akibat pengetahuan yang diterima kurang jelas (Oktaria \& Putra, 2020). Pemberian penguatan berpengaruh terhadap motivasi belajar anak dengan menyadari kebijakan dengan kompetensi yang dimiliki guru diberikan pelatihan untuk menyesuaikan diri dalam mengajar mengikuti aturan dan kebijakan yang berlaku, sehingga proses pembelajaran menjadi efisien (Pradnyayoni, 2017).

Berdasarkan penelitian ini ditemukan bahwa guru telah mampu menyesuaikan keterampilan mengajar yang dimilikinya dengan perubahan kondisi pembelajaran yang semulanya dilaksanakan secara tatap muka berubah menjadi pembelajaran dalam jaringan (daring). Tentunya hal ini berkaitan dengan kesiapan guru, dimana guru sebagai seorang tenaga pendidik yang profesional dituntut agar mampu beradaptasi dengan cepat dalam pelaksanaan kegiatan belajar daring (Alami, 2020). Temuan pada penelitian ini sejalan dengan beberapa hasil penelitian sebelumnya yang juga mengungkapkan bahwa keterampilan guru pada tahap perencanaan sudah berada dalam kategori baik (Sufiati \& Afifah, 2019). Penelitian lainnya juga menyebutkan bahwa keterampilan guru dalam proses penyusunan kegiatan belajar mengalami peningkatan setelah dilaksanakan pelatihan (Seftiarani et al., 2018). Penelitian berikutnya juga menyatakan bahwa peningkatan keterampilan guru sangat berperan terhadap kemampuan peserta didik, sehingga menjadi salah satu komponen penting dalam pendidikan (Badiah et al., 2020).

Berdasarkan beberapa penelitian tersebut dapat dikatakan bahwa peningkatan keterampilan mengajar guru PAUD sangatlah penting. Dalam pelaksanaan pembelajaran daring keterampilan mengajar guru dilihat dari aspek keterampilan mengadakan variasi, keterampilan bertanya, dan keterampilan memberi penguatan dalam pembelajaran daring sudah termasuk dalam kategori positif, dimana guru telah mampu menyesuaikan keterampilan-keterampilan tersebut dengan pembelajaran daring. Temuantemuan yang didapatkan dari penelitian ini memberikan implikasi yaitu secara teoretis temuan ini dapat digunakan sebagai tambahan informasi mengenai keterampilan mengajar guru dalam pembelajaran berbasis daring khususnya di jenjang pendidikan anak usia dini (PAUD) 


\section{SIMPULAN}

Berdasarkan analisis hasil penelitian dan pembahasan dapat diberikan kesimpulan bahwa secara keseluruhan keterampilan mengajar guru PAUD di wilayah Denpasar Utara tergolong baik. Hal ini dapat dilihat dari aspek keterampilan mengadakan variasi termasuk dalam kriteria positif, keterampilan bertanya termasuk dalam kriteria positif, dan keterampilan memberi penguatan termasuk dalam kriteria positif. Ini menandakan bahwa guru-guru PAUD di Wilayah Denpasar Utara sudah mampu untuk mengembangkan keterampilan mengajar pada pembelajaran daring di era pandemi Covid 19 ini..

\section{DAFTAR RUJUKAN}

Achdiani, Y., \& Rusliyani, A. (2017). Pengetahuan Keterampilan Dasar Mengajar dalam Menyiapkan Guru Sekolah Menengah Kejuruan. Teknobuga, 5(2), 34-43. https://doi.org/10.1529/jtbb.v5i2.15368.

Alami, Y. (2020). Media Pembelajaran Daring pada Masa Covid-19. Jurnal Pendidikan Agama Islam, 2(1), 49-56. https://ejournal.staisyamsululum.ac.id/index.php/jtt/article/view/71.

Asmuni, A. (2020). Problematika Pembelajaran Daring di Masa Pandemi Covid-19 dan Solusi Pemecahannya. Jurnal Paedagogy, 7(4), 281-288. https://doi.org/10.33394/jp.v7i4.2941,

Aulia, V. (2018). Implementasi Keterampilan Mengadakan Variasi pada Praktik Pengalaman Lapangan Mahasiswa Program Studi Pendidikan Bahasa Inggris STKIP PGRI Banjarmasin. Jurnal Mitra Manajemen, 2(5), 5-5-521. https://doi.org/https://doi.org/10.52160/ejmm.v2i5.155.

Ayudia, R., Febrialismanto, F., \& Solfiah, Y. (2020). Persepsi Orangtua Terhadap Pembelajaran Daring Pada Anak Usia 5-6 Tahun Di Kecamatan Limapuluh Kota Pekanbaru. Jurnal Review Pendidikan Dan Pengajaran, 3(2), 243-248. https://doi.org/10.31004/jrpp.v3i2.1222.

Ayuni, D., Marini, T., Fauziddin, M., \& Pahrul, Y. (2020). Kesiapan Guru TK Menghadapi Pembelajaran Daring Masa Pandemi Covid-19. Jurnal Obsesi : Jurnal Pendidikan Anak Usia Dini, 5(1), 414-421. https://doi.org/10.31004/obsesi.v5i1.579.

Badiah, L. I., Jauhari, M. N., \& Sambira, S. (2020). Peningkatan Keterampilan Guru Paud Dalam Menyusun Program Pembelajaran Individual Anak Berkebutuhan Khusus Di PAUD Permata Bunda. SPEED Journal : Journal of Special Education, 3(2), 95-100. https://doi.org/10.31537/speed.v3i2.287.

Bungsu, P., \& Saridewi. (2021). Dampak Pembelajaran Dalam Jaringan ( Daring) Terhadap Perkembangan Motorik Kasar Anak Usia Dini. Jurnal Pendidikan, 5(1), 11-20. https://journal.umtas.ac.id/index.php/EARLYCHILDHOOD/article/view/1229/645.

Fadlilah, A. N. (2020). Strategi Menghidupkan Motivasi Belajar Anak Usia Dini Selama Pandemi CoVID-19 melalui Publikasi. Jurnal Obsesi: Jurnal Pendidikan Anak Usia Dini, 5(1), 373-384. https://doi.org/10.31004/obsesi.v5i1.548.

Fitriyani, Y., Fauzi, I., \& Sari, M. Z. (2020). Motivasi Belajar Mahasiswa Pada Pembelajaran Daring Selama Pandemik Covid-19. Jurnal Kependidikan, 6(2), 165-175. https://doi.org/10.33394/jk.v6i2.2654.

Habibi, A. A., \& Firmansyah, R. A. (2019). Analisis Keterampilan Dasar Mengajar Guru Kimia yang mengkuti MGMP MIPA. Journal of Educational Chemistry (JEC), 1(1), 9-16. https://doi.org/10.21580/jec.2019.1.1.3743.

Harahap, S. A., Dimyati, D., \& Purwanta, E. (2021). Problematika Pembelajaran Daring dan Luring Anak Usia Dini bagi Guru dan Orang tua di Masa Pandemi Covid 19. Jurnal Obsesi : Jurnal Pendidikan Anak Usia Dini, 5(2), 1825-1836. https://doi.org/10.31004/obsesi.v5i2.1013.

Jaya, H. N. (2017). Keterampilan Dasar Guru untuk Menciptakan Suasana Belajar yang Menyenangkan. Pendidikan Dan Ilmu Pengetahuan, 17(1), 23-35. https://doi.org/10.30651/didaktis.v17i1.1555.

Kurniati, T., \& Liani, U. (2019). Peningkatan Keterampilan Mengadakan Variasi pada Mahasiswa Program Studi Pendidikan Kimia. Jurnal Ilmiah Ar-Razi, 7(1), 33-38. http://dx.doi.org/10.29406/arr.v7i1.1379.

Mufidah, I., \& Asmawi, H. (2017). Komunikasi Interpersonal dan Keterampilan Memberi Penguatan : Sebuah Analisa Korelasional terhadap Minat Belajar Siswa. Palapa, 5(2), 1-19. https://doi.org/10.36088/palapa.v5i2.43.

Nuralan, S., \& Daipatama, S. T. (2020). Analisis Proses Mengajar Guru Kelas Dalam Pembelajaran Luring Pada Masa Pandemi Covid - 19 Terhadap Siswa Tunagrahita Di Sekolah Luar Biasa Negeri Tolitoli. Nusantara: Jurnal Ilmu Pendidikan, 1(2), 47-57. https://ojs.umada.ac.id/index.php/nusantara_ umada/article/view/131/129.

Oktaria, R., \& Putra, P. (2020). Pendidikan Anak Dalam Keluarga Sebagai Strategi Pendidikan Anak Usia Dini Saat Pandemi Covid-19. Jurnal Ilmiah Pesona PAUD, 7(1), 41. https://doi.org/10.24036/108806.

Palestina, S. (2021). Efektifitas Penggunaan Daring Bagi Anak PAUD. Jurnal Pendidikan Usia Dini, 5(1). https://doi.org/https://doi.org/10.24853/yby.v5i1.9302. 
Permanasari, A. T., Lestari, D. J., \& Fujiawati, F. S. (2018). Penerapan Pembelajaran Tari Untuk Anak Usia Dini Dalam Mengembangkan Kreativitas Mahasiswa Jurusan Pendidikan Sendratasik Untirta. Jurnal Pendidikan Dan Kajian https://doi.org/http://dx.doi.org/10.30870/jpks.v3i2.6916.

Pradnyayoni, W. (2017). Keterampilan Dasar Mengajar Memberi Penguatan Pada Siswa Sekolah Dasar. Pendidikan Dasar, 1(1), 1-48. https://doi.org/http://dx.doi.org/10.25078/aw.v2i1.953.

Putri, A. N., Nurhasanah, A., \& Hakim, Z. R. (2017). Proses interaksi sosial untuk meningkatkan karakter percaya diri siswa kelas 1 SDN tanggerang 19. JPD: Jurnal Pendidikan Dasar, 1(1), 157-170. http://journal.unj.ac.id/unj/index.php/jpd/article/view/16429/9726.

Saifulloh, A. M., \& Darwis, M. (2020). Manajemen Pembelajaran dalam Meningkatkan Efektivitas Proses Belajar Mengajar di Masa Pandemi Covid-19. Bidayatuna: Jurnal Pendidikan Guru Mandrasah Ibtidaiyah, 3(2), 285. https: //doi.org/10.36835/bidayatu.na.v3i2.638.

Saud, U. S. (2011). Pengembangan Profesi Guru. Alfabeta.

Seftiarani, R., Sofia, A., Anggraini, G. F., \& Sabdaningtyas, L. (2018). Kreativitas Guru dan Kompetensi Pedagogik di PAUD Kecamatan Penengahan. Jurnal Pendidikan Anak, 4(2). http://jurnal.fkip.unila.ac.id/index.php/PAUD/article/view/16981.

Setyowahyudi, R., \& Ferdiyanti, T. (2020). Keterampilan Guru PAUD Kabupaten Ponorogo Dalam Memberikan Penguatan Selama Masa Pandemi COVID-19. Jurnal Golden Age, 4(01), 100-111. https://doi.org/10.29408/jga.v4i01.2167.

Srihartini, Y., \& Lestari, M. P. (2021). Pembelajaran Pendidikan Anak Usia Dini Online di Era Pandemi Covid-19. Tarbiatuna: Journal of Islamic Education Studies, 1(1). https://doi.org/10.47467/tarbiatuna.v1i1.219.

Subakti, H., \& Handayani, E. S. (2021). Analisis Keterampilan Mengajar Guru dalam Pembelajaran Bahasa Indonesia Daring pada Siswa Sekolah Dasar. Diglosia: Jurnal Pendidikan, 5(1), 202-210. http://jurnal.unma.ac.id/index.php/dl/article/view/2539.

Subarkah, M. A. (2019). Pengaruh Gadget Terhadap Perkembangan Anak. Rausyan Fikr : Jurnal Pemikiran Dan Pencerahan, 15(1). https://doi.org/10.31000/rf.v15i1.1374.

Sufiati, V., \& Afifah, S. N. (2019). Peran perencanaan pembelajaran untuk performance mengajar guru pendidikan anak usia dini. Jurnal Pendidikan Anak, 8(1), 48-53. https://doi.org/10.21831/jpa.v8i1.26609. https://doi.org/10.36722/jaudhi.v2i1.575.

Suhendro, E. (2020). Strategi Pembelajaran Pendidikan Anak Usia Dini di Masa Pandemi Covid-19. Golden Age: Jurnal Ilmiah Tumbuh Kembang Anak Usia Dini, 5(3), 133-140. https://doi.org/10.14421/jga.2020.53-05.

Sukitman, Trizid, A. (2020). Peran Guru Pada Masa Pandemi Covid-19. Prosiding Diskusi Daring Tematik Nasional, 91-95. http://research-report.umm.ac.id/index.php/psnpb/article/view/3655.

Sunarto, I., \& Rohita, R. (2021). Penguasaan Keterampilan Bertanya Dasar Di Tk Baiturrahman. Jurnal Anak Usia Dini Holistik Integratif (AUDHI), 2(1), 1.

Sundari, F. S., \& Muliyawati, Y. (2017). Analisis Keterampilan Dasar Mengajar Mahasiswa PGSD. Pedagonal : Jurnal Ilmiah Pendidikan, 1(1), 26-36. https://doi.org/10.33751/pedagog.v1i1.225.

Taufik, A. (2018). Keterampilan Komunikasi Guru Profesional di Sekolah. Ijtimaiyah, 2(1), 1-16. http://jurnal.uinsu.ac.id/index.php/ijtimaiyah/article/view/2921.

Yuniarni, D. (2016). Peran Paud Dalam Mengoptimalkan Tumbuh Kembang Anak Usia Dini Demi Membangun Masa Depan Bangsa. Jurnal Visi Ilmu Pendidikan, 8(1). https://doi.org/10.26418/jvip.v8i1.27370.

Zein, R., \& Maielfi, D. (2020). Penerapan keterampilan bertanya mahasiswa untuk stimulasi keterampilan berpikir tingkat tinggi (HOTs) anak TK. Ațāluna: Journal of Islamic Early Childhood Education, 3(1), 1-12. https://doi.org/10.32505/atfaluna.v3i1.1644. 